involved to another constructional problem, this time a vital question of formwork for concrete as used in the 540-MW hydro-electric scheme in New Zealand; this is what is known as the Benmore project on the Waitak River, South Island, designed to ". . . contain six 90,000kilowatt generators producing $540 \mathrm{MW}$ of electricity" and "... will feed into the national grid, which, by means of a cable under Cook Strait, will supply the North Island as well ...". A.ccording to an article entitled "A.erolite-glued Formwork for Concrete", some 450,000 cubic yards of concrete are involved in this project, most of which was cast using timber formwork (Ciba (A.R.L.), Ltd. Technical Notes, No. 259, July 1964. Pp. 8. Duxford: Ciba (A.R.L.), Ltd., 1964). In concrete construction, especially for river dams such as this, there is a recent tendency towards larger and higher pours; formwork therefore has to withstand greater pressures than before. When the motive is also economy, there is a rational trend towards the use of units which can be used repeatedly; essential criteria are extra strength, quick release and easy handling. "It was found that all these characteristics could be facilitated by the use of glue laminated timber structures incorporating Aerolite adhesive." In a report by D. R. Douglas, structural design draughtsman on this project, quoted in the article, he remarks on the big advantages obtained by the use of glue laminated work. "The choice of laminating or of using solid timber for forms was determined mainly by the importance of the component in relation to the whole form or by the need for stability or alignment. With a rainfall averaging 15 in. or less per year, and with the very low humidity of the district, all timbers dried out and tended to distort more than they would have in many other places. For this reason alone, the lamination of critical members was preferred." The several excellent illustrations accompanying this article clearly show the manner in which this glued formwork is prepared, assembled and used; it is a technique which will become increasingly popular in similar circumstances elsewhere.

Palæontology in the U.S.S.R.

THE recent volumes of the Transactions of the Paloeontological Institute (Moscow) (Nature, 197, 854; 1963; 199, 1139; 1963) are: (98) Bryozoa of the Borshchovsky and Chortkovsky horizons of Podolia, by G. G. Astrova (1964). These two horizons were originally placed in the Upper Silurian, but the present author proves them to be of Lower Devonian age; 150 specimens belonging to 24 species are described. (99) Biometric study of Pliocene vivipari of the southern part of the U.S.S.R. by V. Ya. Taboyarkova (1964). (100) The historical development of Diptera, by B. B. Rodendorf (1964). (101) Tabulates of the Lower and Middle Devonian age in the Kuznetsk Basin, by I. I. Chudinova (1964). (102) Conditions of life of the Silurian and Devonian marine fauna in the Kuznetsk, Minusinsk and Tuva Basins, by E. A. Ivanova, T. N. Bel'skaya and I. I. Chudinova (1964).

\section{Bleeding in the Surgical Patient}

Surgeons throughout the world can scarcely fail to be interested in the recent issue of the Annals of the New York Academy of Sciences entitled Bleeding in the Surgical Patient, in which 68 experts, who met at a conference held by the Academy in May 1963, discuss various aspects of the general problem of bleeding during, or after, surgical operations (115, Article 1. By Seymour Gollub, Alex W. Ulin and 77 other authors. Pp. 1-542. New York: New York Academy of Sciences, 1964. 7 dollars). This has been and, as the first paper in this series explains, still is, a fundamental problem for the surgeon. Great advances in the control of hæmorrhage have, of course, been made since Lister showed that blood vessels could be ligatured. Nowadays the detailed biochemical investigation of the various factors concerned in blood coagulation would seem to be in the foreground, but hypothermia, blood transfusion, advances in anæstheties and a number of other factors discussed here have also played important parts in the reduction of the consequences of operations and the mortality formerly due to them.

\section{Congenital Absence of Pain}

Dr. H. J. Kingsley and Dr. J. E. A. David of Bulawayo have described (Central African Journal of Medicine, 10 $(8), 1964)$ the case of a girl aged 22 months. She was subject to temper tantrums, and during those tantrums would bang herself on the head or bite herself. She appeared to be completely insensitive to pain. She is a well-built, sturdy little girl and, apart from the bandiness of her legs and a photosensitive skin rash, no physical abnormalities were found. Mentally, it was thought she might be a little backward. She was admitted to hospital for investigation and was noticed to have periods of blankness which were thought to be some typo of petit mal. Many investigations were made and all results were normal. While she was in hospital her sensitivity to pain was tested and it was found that the child was insensitive to pain almost all over the trunk, limbs and face, and a sterile hypodermic needlo could be stuck through the skin to the subcutaneous tissues without any flinching. She was apparently insensitive to heat and cold and to light touch, but these were difficult to evaluate. Winkelmann and his colleagues have previously reported a case of congenital universal indifference to pain in a 9-year-old white boy, with detailed anatomical, clinical and physiological studies. Confusion exists in the literature about congenital absence of pain, and a complete neurological examination should be carried out in these cases; specific attention should be directed towards the discovery of isolated islands of normal sensation, particularly round the trunk, genitals and face. This type of insensitivity is usually congenital and the patient is usually of normal intelligence, development and psychic adjustment. In a case described by Winkelmann, Lamber and Hayles no norve end organs (Meissnor or Vater-Pacini corpuscles) were found in any of the skin specimens studied. Dr. Walter B. Shelley of Philadelphia thinks that these cases are not as rare as is supposed and that there are people who experience coronary thrombosis or a perforating appendicitis, or have babies, without pain. Apparently, where pain is absent, itching is also absent.

University News:

Bradford

The Governing Body and the Academic Advisory Committee of the Bradford Institute of Technology have announced the establishment of 30 professorships. The following heads of department become the first 12 professors in the fields concerned: Dr. E. Lees (biological sciences); Dr. R. L. Elliott (chemical technology); C. W. Page (chemical engineering); Dr. C. B. Wilby (civil engineering); Dr. G. N. Patchett (electrical engineering); J. G. Jagger (mechanical engineering); T. Kempner (management); Dr. J. G. Freeman (mathematics); Dr. J. M. Rowson (pharmacy); Dr. D. L. Smare (physics); P. H. Coles (social sciences); Dr. F. Happey (textiles).

London

Dr. J. W. BoAG, physicist in the Research Unit in Radiobiology at Mount Vernon Hospital, has been appointed to the chair of physics as applied to medicine tenable at the Institute of Cancer Research, Royal Cancer Hospital. Dr. E. W. Emery, senior lecturer in medical physies in the University of Manchester, has been appointed to the readership in medical physics tenable at the Postgraduate Medical School of London from April 1. The following titles have been conferred: Professor, on Dr. D. R. Laurenco (pharmacology and therapeutics), in respect of his post at University College and University College Hospital Medical School. Reader, on Dr. P. N. Campbell (biochemistry), in respect of his post at Middlesex Hospital Medical School; on Miss N. F. T. Crowley (bacteriology), in respect of her post at the Royal Free 